\title{
Long-term trends in river flow: a case study of the Sola River (Polish Carpathians)
}

\author{
Mariola $\mathrm{Kędra}^{1, *}$ \\ ${ }^{1}$ Cracow University of Technology, Department of Environmental Engineering, Institute of Engineering and Water Management, \\ Warszawska 24, 31-151 Cracow, Poland
}

\begin{abstract}
This study analyses potential trends in river flow for the most recent 60 years (19562015). The study area is situated in the Soła catchment in the Polish Carpathians. The focus of the study was to evaluate long-term trends in mean monthly river flow for each season of the year as well as to compare the direction of these trends for sites located a distance upstream and downstream from a cascade of three dams built on the Soła River. Moreover, potential long-term trends in seasonal precipitation were also studied. The data indicate a significant increase in minimum discharge during the winter for the upstream site. Increases in mean and maximum discharge are significant for spring at that site as well. In contrast, a significant decrease in minimum discharge was identified for the downstream site during the spring. Moreover, significant decreases in mean and minimum discharge were noted for the summer season at the downstream site only. No trends in discharge were identified for the autumn at either site. Significant trends in precipitation were noted for each season of the year, with increases during the winter, spring, and autumn (3.6-9.8 mm per decade) in the vicinity of the upstream site, but a decrease in minimum summer precipitation $(-5.0 \mathrm{~mm}$ per decade) at the downstream site. The revealed differences in the direction of seasonal trends for the upstream and downstream sites studied suggest an anthropogenic impact on river flow downstream from the cascade of dams. Overall, the identified decrease in summer discharge at the downstream site, accompanied by a decrease in summer precipitation, indicate the need for adaptive water management in the studied catchment to ensure water availability for the summer season.
\end{abstract}

\section{Introduction}

In mountain regions of mid-latitudes, stream and rivers are typically rich in water owing to substantial orographic precipitation. Unpolluted rivers with well oxygenated water of relatively low temperatures throughout the year and dynamic flow create suitable environmental conditions for cold water species [1]. Mountain rivers are also affected by human activity, which directly (water diversion, dam and reservoir construction, channel engineering works) or indirectly (urbanization, removal of vegetation, road construction) [2-3], alters flow and thermal conditions, impairing river ecosystems [4]. Of direct interventions in river environments, the construction of dams and the changes to fluvial environments that they introduce, have been well documented [5-16]. Dams essentially alter the downstream flow of water and sediment, modifying biochemical cycles and the habitat structure [17]. Dams with hypolimnetic (bottom layer) water releases can weaken the synchronous behaviour of air and water temperatures and significantly change water temperature dynamics in the downstream river section [18-19].
Moreover, fragmentation of free-flowing rivers by dams causes disadvantageous ecosystem isolation [17].

The impact of a changing climate, mainly atmospheric warming, on freshwater resources and the functioning of aquatic ecosystems has been extensively studied over the last few decades [20-27]. The warming trend in global mean surface air temperature of $0.12{ }^{\circ} \mathrm{C}$ per decade (1951-2012) [28], accompanied by likely changes in precipitation [29], may worsen flow and thermal conditions in fluvial environments, with serious implications for both aquatic life and humans. Therefore, ensuring sufficient freshwater resources for domestic, agricultural, and industrial use, while maintaining environmental flows for ecological health of rivers [30], is one of the most important management concerns in a changing climate. In this context, the identification of significant changes and long-term trends in hydroclimatic variables such as river flow and precipitation may give rise to a more realistic planning and management effort for existing water resources.

The aim of this study is to: (1) assess potential longterm (60-year) trends in river flow for each season of the year; (2) compare the direction of these trends for sites

Corresponding author: mariola.kedra@iigw.pk.edu.pl 
located a distance upstream and downstream from a cascade of three dams built on a mountain river in the Polish Carpathians; (3) compare potential trends in seasonal values of river flow $(Q)$ and precipitation $(P)$ for nearby sites. Detection of statistically significant trends in $Q$ and $P$ can facilitate future water management and planning in the studied mountain river catchment; it may also serve as the basis for informed decisions that mitigate adverse effects of a changing climate in key water source areas, especially in mountain river basins.

\section{Materials and methods}

\subsection{Study area}

The research was carried out on the Carpathian river Soła, the right-bank tributary of the upper Vistula River in southern Poland (Fig. 1). From its source in the Żywiec Beskids $1070 \mathrm{~m}$ above sea level (a.s.1.) to its mouth $227 \mathrm{~m}$ a.s.l., the Soła River is $89 \mathrm{~km}$ in length [31].

The Soła catchment covers an area of $1,391 \mathrm{~km}^{2}$ [31], with the highest peak (Pilsko: 1,557 $\mathrm{m}$ ) being located in the Żywiec Beskids, and the lowest elevation at the Soła River mouth. The rock layer underlying the Soła catchment is mainly composed of sandstone, loam, shale, and gravel [32].

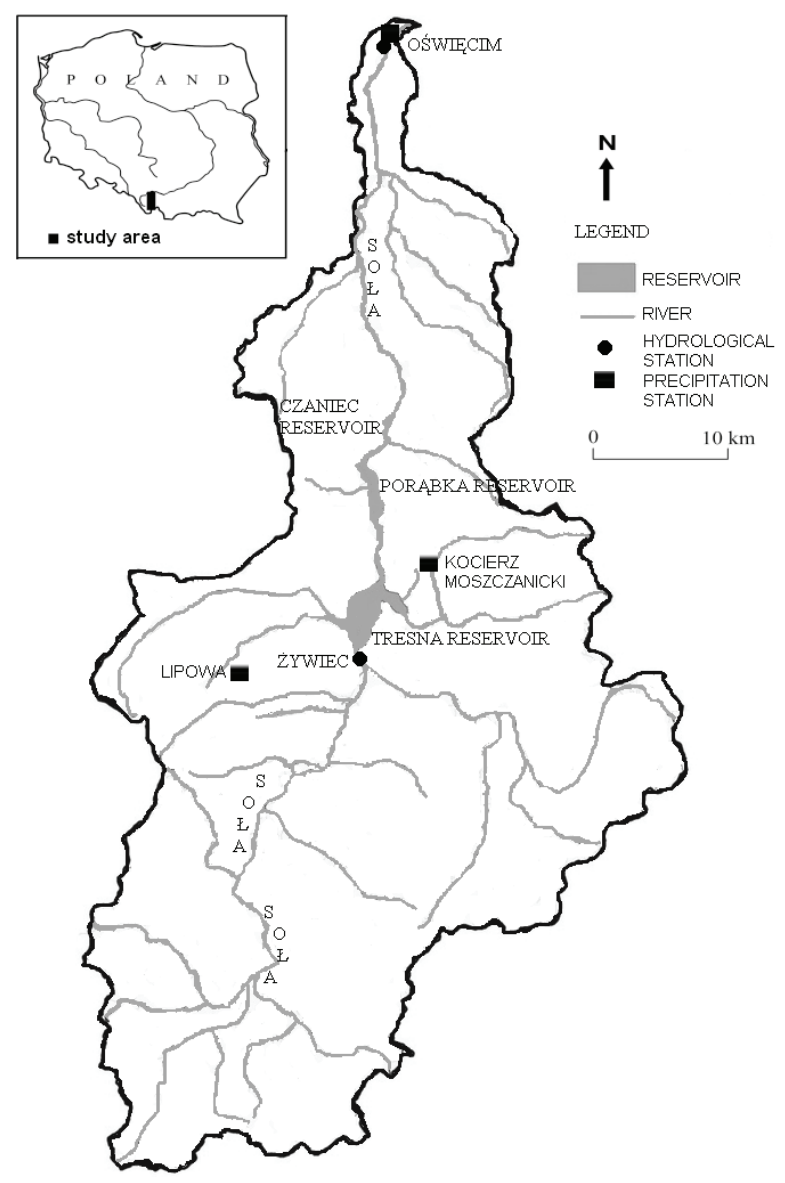

Fig. 1. Study area - the Soła River catchment with larger tributaries and observation sites used.
Climate conditions in the study area vary depending on location. In the lower-lying parts of the catchment, the air temperature is higher, with an annual average of 6-8 ${ }^{\circ} \mathrm{C}$, and precipitation totals of $600-800 \mathrm{~mm}$ a year. The highest peaks in the Silesian and Żywiec Beskids are characterised by a cool climate with the annual mean air temperature below $4{ }^{\circ} \mathrm{C}$ and annual precipitation totals reaching $1,400 \mathrm{~mm}[33]$.

According to CLC mapping [34], the Soła catchment area is $51.5 \%$ forested, while agricultural and developed lands comprise $36.9 \%$ and $10.0 \%$, respectively, while waters cover $1.6 \%$. A cascade of three dams (Tresna, Porąbka, and Czaniec) was built between 1936 and 1967 on the Soła River [35]. Physical characteristics of the studied reservoirs are listed in Table 1.

Table 1. Physical characteristics of the studied reservoirs [35].

\begin{tabular}{|c|c|c|c|}
\hline Statistic & Tresna & Porąbka & Czaniec \\
\hline $\begin{array}{l}\text { River length } \\
(\mathrm{km})\end{array}$ & 41.9 & 34.6 & 31.0 \\
\hline $\begin{array}{l}\text { Drainage area } \\
\qquad\left(\mathrm{km}^{2}\right)\end{array}$ & 1037 & 1091 & 1120 \\
\hline 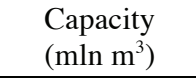 & 94.6 & 28.4 & 1.2 \\
\hline $\begin{array}{l}\text { Depth } \\
\text { (m) }\end{array}$ & 23.0 & 23.8 & 7.5 \\
\hline $\begin{array}{l}\text { Surface area } \\
\qquad\left(\mathrm{km}^{2}\right)\end{array}$ & 10.00 & 3.67 & 0.45 \\
\hline $\begin{array}{c}\text { Year of } \\
\text { construction }\end{array}$ & 1967 & 1936 & 1967 \\
\hline Functions $^{\mathrm{a}}$ & $\begin{array}{c}\text { F, S, E, } \\
\text { L(6.7) }\end{array}$ & $\begin{array}{c}\mathrm{F}, \mathrm{S}, \mathrm{E}, \\
\mathrm{L}(8.5)\end{array}$ & $\mathrm{B}, \mathrm{E}$ \\
\hline
\end{tabular}

\subsection{Data and methods}

\subsubsection{Data}

The considered river flow series consist of monthly means for two gauging sites (Żywiec and Oświęcim) situated along the middle and lower course of the Soła River, respectively (Table 2). Monthly precipitation totals for nearby sites (Lipowa, Kocierz Moszczanicki, and Oświęcim) were also taken into account (Table 3). The available flow data for the Żywiec site begin in November 1955; this yields the longest feasible time period studied (60 years), with consecutive seasons from winter (December 1955, January and February 1956) to autumn 2015. Monthly flow and precipitation data for the years 1956-2015 (December 1955 - November 2015) were made available for research purposes by the Polish Institute of Meteorology and Water Management-the National Research Institute; precipitation data for the town of Oświęcim for the years 1956-1980 were obtained from Polish state precipitation yearbooks. The Żywiec site is adjacent to the upper part 
of the Tresna Reservoir (TR), and Oświęcim is located $28 \mathrm{~km}$ downstream from the Czaniec Reservoir (CR).

Table 2. Physical characteristics of the study sites [31] and descriptive statistics of mean monthly discharge data for the 60-year period (1956-2015).

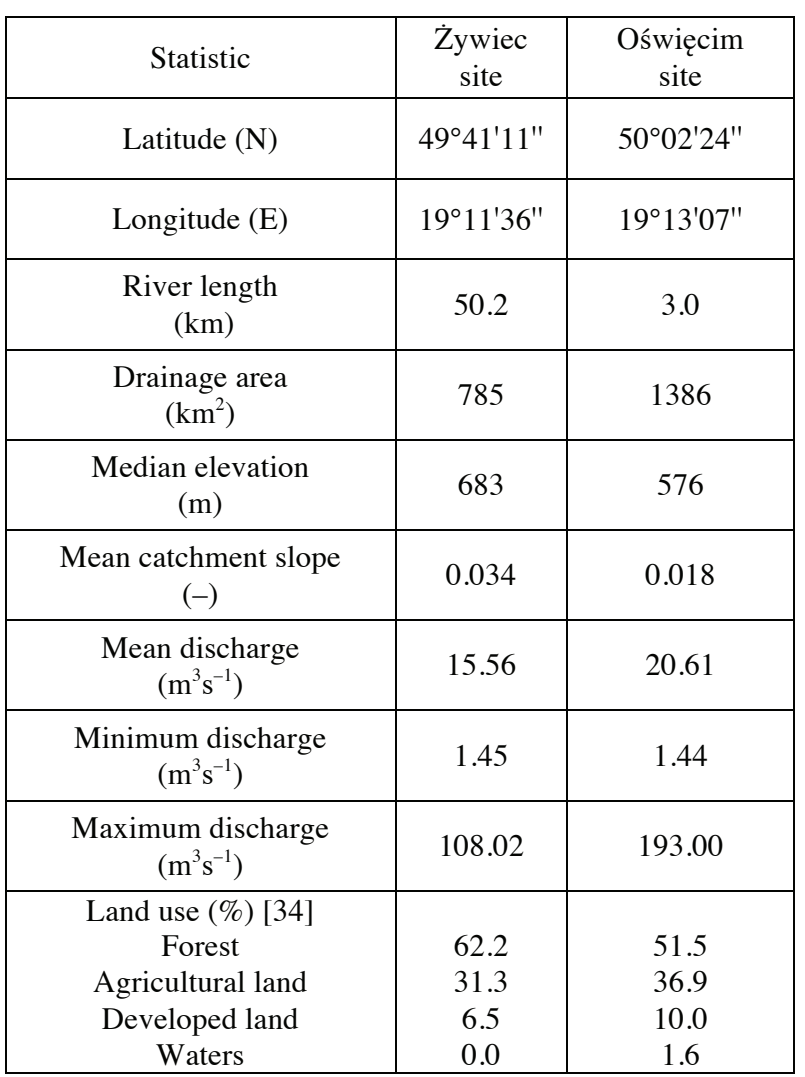

Table 3. Details of precipitation sites used. Mean annual precipitation was calculated using monthly data for 1956-2015.

\begin{tabular}{|c|c|c|c|}
\hline Statistic & $\begin{array}{c}\text { Lipowa } \\
\text { site }\end{array}$ & $\begin{array}{c}\text { Kocierz } \\
\text { Moszcza- } \\
\text { nicki site }\end{array}$ & $\begin{array}{c}\text { Oświęcim } \\
\text { site }\end{array}$ \\
\hline Latitude (N) & $49^{\circ} 39^{\prime} 58^{\prime \prime}$ & $49^{\circ} 44^{\prime} 25^{\prime \prime}$ & $50^{\circ} 02^{\prime} 23^{\prime \prime}$ \\
\hline Longitude (E) & $19^{\circ} 04^{\prime} 36^{\prime \prime}$ & $19^{\circ} 15^{\prime} 17^{\prime \prime}$ & $19^{\circ} 14^{\prime} 50^{\prime \prime}$ \\
\hline $\begin{array}{c}\text { Altitude } \\
\text { (m a.s.1.) }\end{array}$ & 530 & 430 & 243 \\
\hline $\begin{array}{c}\text { Mean annual } P \\
\text { (mm) }\end{array}$ & 1040.5 & 1083.1 & 751.8 \\
\hline
\end{tabular}

\subsubsection{Methods}

After visual inspection of monthly data compiled in a Microsoft ${ }^{\circledR}$ Excel 2007 spreadsheet, a quality check was performed in order to detect spurious values. Subsequently, each 720-element series was arranged as the matrix $\boldsymbol{M}_{i k}$, where the index $i$ (for row) represents a year $(i=1, \ldots, n), n=60$, and the index $k$ (for column) represents a month $(k=1, \ldots, 12)$. For each season (winter-autumn) of the year (1956-2015), that is, for the relevant three columns of the matrix $(1-3,4-6,7-9,10-$ 12), arithmetic mean, minimum, and maximum values were computed as time series $\left\{x_{i}, i=1, \ldots, n\right\}$. Next, trend analysis was performed on each seasonal series $\left\{x_{i}\right\}$ separately in order to assess the strength of potential monotonic trends in seasonal values of $Q$ and $P$. The linear model of time trend was assumed in the form: $x(t)=a \cdot t+b$, where $a$ is the slope coefficient, $b$ is the intercept, and $t$ is time. The non-parametric, 2-sided Mann-Kendall test (MK)[36-38] was used. The null hypothesis of no trend $\left(\mathrm{H}_{0}: a=0\right)$ was tested equivalently $\left(\mathrm{H}_{0}: \tau=0\right)$, using Kendall's rank correlation coefficient $\tau$ [36-38] at the significance level $\alpha: 0.05$ (medium evidence) and 0.01 (strong evidence). The $\tau$ is expressed as:

$$
\begin{gathered}
\tau=\frac{2 S}{n(n-1)} \\
S=\sum_{i=1}^{n-1} \sum_{j=i+1}^{n} \operatorname{sign}\left(x_{j}-x_{i}\right)
\end{gathered}
$$

where: $S$ is Kendall's $S$ statistic, and $\operatorname{sign}(x)$ is the sign function. The magnitude of trends was determined using Theil-Sen's slope [38-40] as a robust estimate of the slope, with the slope and intercept defined as:

$$
\begin{gathered}
\hat{a}=\operatorname{median}\left(\frac{x_{j}-x_{i}}{t_{j}-t_{i}}\right), i=1, \cdots, n-1, j=i+1, \cdots, n \\
\hat{b}=\operatorname{median}\left(\left\{x_{i}\right\}_{i=1}^{n}\right)-\hat{a} \operatorname{median}\left(\left\{t_{i}\right\}_{i=1}^{n}\right)
\end{gathered}
$$

No assumption of normality, but serial interdependence is required for the MK test [38]. Therefore, the trend-free pre-whitening procedure (TFPW) [41] was applied to each data series.

\section{Results and discussion}

For the river discharge studied, significant trends $(p<0.05)$ were identified for each season of the year (Table 4) except autumn (September-November). For winter (December-February, Fig. 2) and spring (MarchMay, Fig. 3), increasing trends were noted for the upstream site (Żywiec) only; an increase in minimum $Q$ $\left(0.67 \mathrm{~m}^{3} \mathrm{~s}^{-1}\right.$ per decade, strong evidence) during the winter was followed by an increase in mean and maximum $Q$ during the spring (1.35 and $2.03 \mathrm{~m}^{3} \mathrm{~s}^{-1}$ per decade, respectively, Figs. 3a-b). In contrast, a significant decrease in minimum $Q\left(-1.29 \mathrm{~m}^{3} \mathrm{~s}^{-1}\right.$ per decade, Fig. 3c) was identified for the downstream site (Oświęcim) during the spring season. Moreover, significant decreasing trends in mean and minimum $Q$ were identified for summer (June-August) at the downstream site only, with a rate of change of 2.18 and $1.05 \mathrm{~m}^{3} \mathrm{~s}^{-1}$ per decade, respectively (Fig. 4), while remaining trends in summer $Q$ were found to be decreasing as well, but remained statistically insignificant (at $p<0.05$ ).

For precipitation, significant trends $(p<0.05)$ were identified for each season of the year (Table 5). For winter, an increase in mean, minimum, and maximum $P$ (3.6-5.5 mm per decade) was identified at one site (Lipowa, approximately $8.4 \mathrm{~km} \mathrm{~W}$ from Żywiec). For spring, an increase in mean and maximum $P$ (3.7-9.0 $\mathrm{mm}$ per decade) was found at one site as well (Kocierz Moszczanicki, approximately $8.0 \mathrm{~km} \mathrm{NE}$ from Żywiec). 
On the other hand, a decrease in minimum $P(-5.0 \mathrm{~mm}$ per decade) was identified during the summer at the downstream site only (Oświęcim). Moreover, increasing trends in autumn $P$ (5.2-9.8 $\mathrm{mm}$ per decade) were found at the two sites (Lipowa and Kocierz Moszczanicki) in the vicinity of Żywiec.

Table 4. Rate of change $\hat{a}\left(\mathrm{~m}^{3} \mathrm{~s}^{-1}\right.$ decade $\left.^{-1}\right)$ for river flow $(Q)$ in each season of the year (1956-2015) based on Theil-Sen's slope estimation [39-40] with trend free pre-whitening [41]. Statistical significance of the trends was evaluated via the 2-sided Mann-Kendall test [36-37].

\begin{tabular}{|c|c|c|c|c|}
\hline$Q$ statistic & $\begin{array}{c}\text { Winter } \\
\text { (Dec- } \\
\text { Feb) }\end{array}$ & $\begin{array}{c}\text { Spring } \\
\text { (Mar- } \\
\text { May) }\end{array}$ & $\begin{array}{c}\text { Summer } \\
\text { (Jun- } \\
\text { Aug) }\end{array}$ & $\begin{array}{c}\text { Autumn } \\
\text { (Sep- } \\
\text { Nov) }\end{array}$ \\
\hline $\begin{array}{c}\text { Mean } \\
\text { (Żywiec) }\end{array}$ & 0.74 & $1.35^{* *}$ & -1.02 & 0.58 \\
\hline $\begin{array}{c}\text { Minimum } \\
\text { (Żywiec) }\end{array}$ & $0.67 * *$ & 0.11 & -0.40 & 0.11 \\
\hline $\begin{array}{c}\text { Maximum } \\
\text { (Żywiec) }\end{array}$ & 0.72 & $2.03^{*}$ & -1.82 & 1.00 \\
\hline $\begin{array}{c}\text { Mean } \\
\text { (Oświęcim) }\end{array}$ & 0.34 & 0.57 & $-2.18^{*}$ & 0.12 \\
\hline $\begin{array}{c}\text { Minimum } \\
\text { (Oświęcim) }\end{array}$ & 0.03 & $-1.29 *$ & $-1.05^{* *}$ & -0.02 \\
\hline $\begin{array}{c}\text { Maximum } \\
\text { (Oświęcim) }\end{array}$ & 0.03 & 1.06 & -3.15 & -0.08 \\
\hline
\end{tabular}

$*$ data significant at $p<0.05 ; * *$ data significant at $p<0.01$.

Table 5. Rate of change $\hat{a}\left(\mathrm{~mm}\right.$ decade $\left.^{-1}\right)$ for precipitation $(P)$ in each season of the year (1956-2015) based on Theil-Sen's slope estimation [39-40] with trend free pre-whitening [41]. Statistical significance of the trends was evaluated via the 2sided Mann-Kendall test [36-37].

\begin{tabular}{|c|c|c|c|c|}
\hline$P$ statistic & $\begin{array}{c}\text { Winter } \\
\text { (Dec- } \\
\text { Feb) }\end{array}$ & $\begin{array}{c}\text { Spring } \\
\text { (Mar- } \\
\text { May) }\end{array}$ & $\begin{array}{c}\text { Summer } \\
\text { (Jun- } \\
\text { Aug) }\end{array}$ & $\begin{array}{c}\text { Autumn } \\
\text { (Sep- } \\
\text { Nov) }\end{array}$ \\
\hline $\begin{array}{c}\text { Mean } \\
\text { (Lipowa) }\end{array}$ & $4.6^{* *}$ & 2.2 & -4.8 & $5.2^{*}$ \\
\hline $\begin{array}{c}\text { Minimum } \\
\text { (Lipowa) }\end{array}$ & $3.6^{*}$ & 1.0 & -2.5 & 1.2 \\
\hline $\begin{array}{c}\text { Maximum } \\
\text { (Lipowa) }\end{array}$ & $5.5^{*}$ & 2.8 & -5.2 & $7.2^{*}$ \\
\hline $\begin{array}{c}\text { Mean } \\
\text { (Kocierz } \\
\text { Moszcz.) }\end{array}$ & 1.3 & $3.7^{*}$ & -3.3 & $5.6^{* *}$ \\
\hline $\begin{array}{c}\text { Minimum } \\
\text { (Kocierz } \\
\text { Moszcz.) }\end{array}$ & 1.7 & 0.5 & -0.4 & 1.8 \\
\hline $\begin{array}{c}\text { Maximum } \\
\text { (Kocierz } \\
\text { Moszcz.) }\end{array}$ & 0.2 & $9.0^{*}$ & -3.8 & $9.8^{*}$ \\
\hline $\begin{array}{c}\text { Mean } \\
\text { (Oświęcim) }\end{array}$ & 0.5 & 1.0 & -3.0 & 1.7 \\
\hline $\begin{array}{c}\text { Minimum } \\
\text { (Ó́więcim) }\end{array}$ & 0.5 & 0.4 & $-5.0^{*}$ & 1.7 \\
\hline $\begin{array}{c}\text { Maximum } \\
\text { (Oświęcim) }\end{array}$ & 0.9 & 2.2 & -2.2 & 1.0 \\
\hline
\end{tabular}

$*$ data significant at $p<0.05$; * data significant at $p<0.01$.

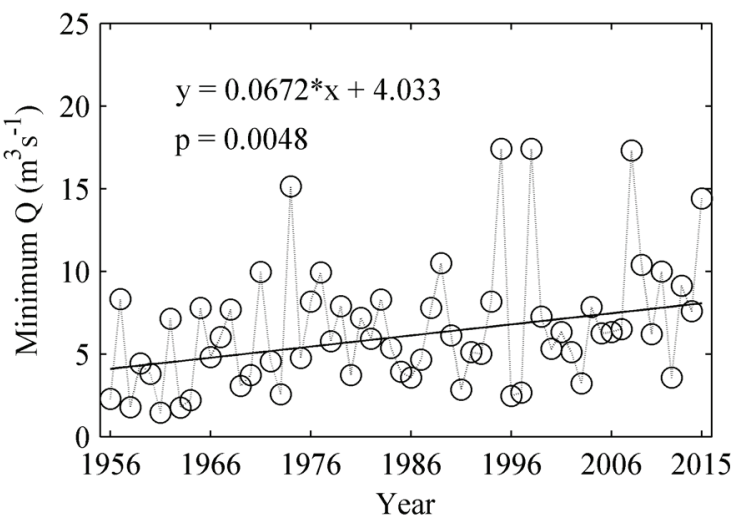

Fig. 2. Winter flow rates $(Q)$ at $̇$ ywiec (upstream from the TR dam) for the 60-year period (1956-2015) with a significant trend shown in minimum $Q$.
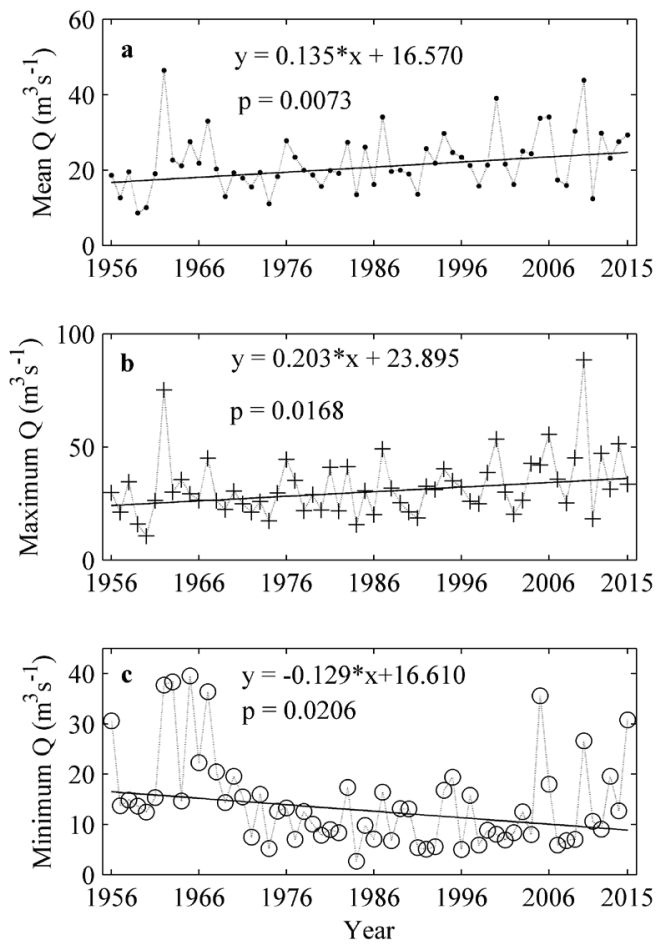

Fig. 3. Spring flow rates $(Q)$ for the 60-year period (19562015) with significant trends shown: at Żywiec (upstream from the TR dam) in mean $Q$ (a) and maximum $Q$ (b); at Oświęcim (downstream from the TR dam) in minimum $Q$ (c).

Direct effects of climate change include changing river temperature and flow patterns [2]. It is also clear that river flow is regarded a master variable, which shapes essential characteristics of fluvial ecosystems [42]. In order to undertake adequate decisions mitigating adverse climate-change impacts on fluvial environments and on existing freshwater resources, an assessment of ongoing changes in flow, especially long-term tendencies, appears crucial and indispensible. In this study, we are focused on a mountain river with long-term flow series pertaining to the most recent 60 years (1956-2015), and on concurrent precipitation from neighbouring sites. 

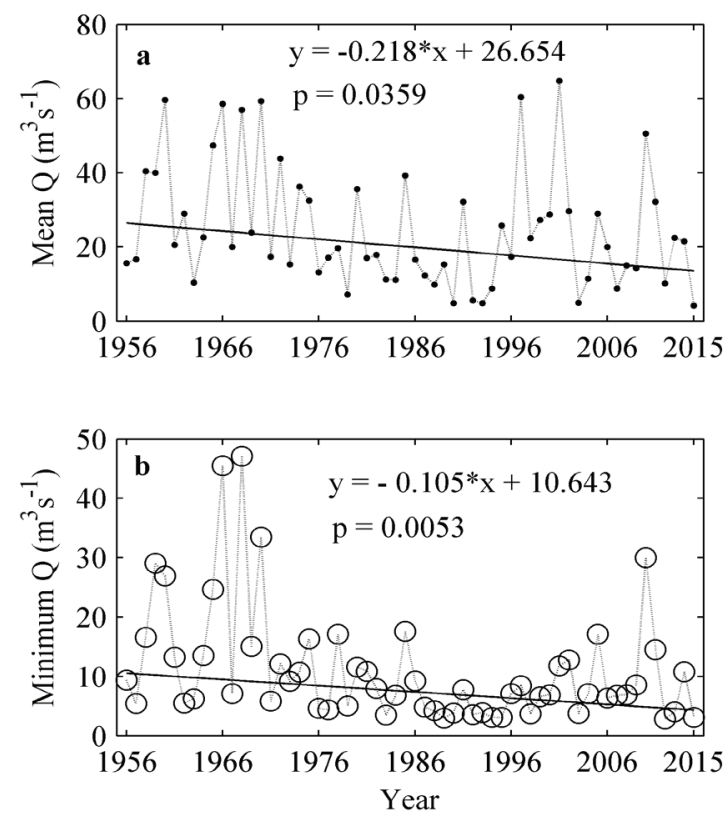

Fig. 4. Summer flow rates $(Q)$ at Oświęcim (downstream of the CR dam) for the 60-year period (1956-2015) with significant trends shown in: (a) mean $Q$; (b) minimum $Q$.

The obtained results suggest that river flow tends to be progressively higher during the winter (minimum values of $Q$ shown for the upstream site, Fig. 2) as well as during the spring (mean and maximum values of $Q$ shown for the upstream site, Figs. 3a-b). An increasing trend in winter $Q$ (at Żywiec) is consistent with a similar trend in winter $P$ (mean, minimum, and maximum values of $P$ at a nearby site, Lipowa). An increasing trend in spring $Q$ can be associated with increased spring precipitation regionally, especially for March and May, as revealed for the neighbouring catchments of the Skawa, Raba, and Dunajec rivers [27, 43]; moreover, it corresponds with an increase in spring $P$ found at Kocierz Moszczanicki. However, such an increasing tendency in spring $Q$ is absent for the downstream site (28 km downstream from the CR dam), and even a decreasing tendency is present (minimum values, Fig. $3 c)$. Moreover, another difference in revealed changes for the upstream and downstream sites pertains to a significant decreasing trend in summer flow rates (mean and minimum values, Fig. 4) for the downstream site only, which is accompanied by a decreasing trend in $P$ (minimum values of $P$ at Oświęcim). On the other hand, summer is the only season when all remaining trends in $Q$ and $P$ (Table 4 and 5, respectively) show a decreasing, yet statistically insignificant, tendency consistent with revealed, significant decreases in summer $Q$ and $P$ for the mentioned nearby catchments $[27,43]$. No trend in autumn $Q$ was identified, while increasing trends in autumn precipitation were found (at Lipowa and Kocierz Moszczanicki).

It seems also relevant to mention that differences in magnitude and/or direction of hydro-climatic trends depend on changes in dynamic interactions between large numbers of factors acting upon mountain river basins. In particular, ongoing land use and land cover changes (LULCC) are widespread in the Carpathians due to a shift in land use after 1990, reflected in farm abandonment and forest expansion [44]. According to CLC mapping, which is now available for the years 1990, 2000, 2006, and 2012, the same direction of LULCC occurred in the Soła catchment over the period 1990-2012. For the Żywiec and Oświęcim subcatchments, increases in forest cover (5.9 and 4.7\%, respectively) and developed land (1.0 and 3.0\%, respectively) occurred at the expense of agricultural land. This implies further differences in land cover between the studied subcatchments (Table 2), suggesting different impacts of LULCC on discharge and precipitation changes during the studied time period, but a detailed analysis is needed to investigate this issue.

Overall, the noted decrease in summer river flow volume at Oświęcim, accompanied by a decreasing trend in summer precipitation, should be carefully studied by the Regional Water Management Board in Cracow, responsible for water management in the Soła catchment. The revealed trends suggest a possible water deficiency during the summer season, indicating the need for adaptive water management of existing water resources in the studied catchment in order to provide an adequate water supply for local residential communities, while preserving environmental flows for the ecological health of rivers [30].

\section{Conclusions}

In the conducted analysis pertaining to changing flow conditions in a mountain river, long-term (60-year) trends in river flow for each season of the year (19562015) except autumn were found. The direction of these trends differs for sites located a distance upstream and downstream from a cascade of three dams. For the upstream site (Żywiec), a significant increase in river flow (minimum values) during the winter is followed by significant increases in flow (mean and maximum values) during the spring. For the downstream site (Oświęcim), significant decreases in flow (mean and minimum values) during the spring and summer are observed. The identified differences suggest an anthropogenic impact on river flow downstream from the studied cascade of the Tresna, Porąbka, and Czaniec reservoirs.

Concomitant, long-term (60-year) trends in precipitation are significant for each season of the year (1956-2015). Increasing tendencies in winter, spring, and autumn $P$ were found in the vicinity of the upstream site, while a decrease in summer $P$ was identified at the downstream site.

In general, the identified decrease in summer discharge at the downstream site, accompanied by a decrease in summer precipitation, suggest the need for adaptive water management in the Soła catchment, due to a likely water deficiency during the summer season.

This work was supported by the Polish Ministry of Science and Higher Education (grant no. Ś1/194/2017/DS task 4). 


\section{References}

1. K. Bieniarz, P. Epler, Ichthyofauna, in: The Upper Vistula Basin, part II (PWN Warszawa-Kraków, pp. 69-81, 1991) (In Polish)

2. J.D. Allan, M.M. Castillo, Stream ecology. Structure and function of running waters (2nd ed., Springer, 2007)

3. G.C. Poole, C.H. Berman, Environ. Manage. 27, 787-802 (2001)

4. B. Babbitt, BioScience 52, 656-658 (2002)

5. R.M. Baxter, Annu. Rev. Ecol. Syst. 8, 255-283 (1977)

6. M.E. Power, W.E. Dietrich, J.C. Finlay, Environ. Manage. 20, 887-895 (1996)

7. G.M. Kondolf, Environ. Manage. 21, 533-551 (1997)

8. N.L. Poff, J.D. Allan, M.B. Bain, J.R. Karr, K.L. Prestegaard, B.D. Richter, R.E. Sparks, J.C. Stromberg, BioScience 47, 769-784 (1997)

9. F.J. Magilligan, K.H. Nislow, B.E. Graber, Geology 31, 569-572 (2003)

10. F.J. Magilligan, K.H. Nislow, Geomorphology 71, 61-78 (2005)

11. G.E. Petts, A.M. Gurnell, Geomorphology 71, 2747 (2005)

12. D. Caissie, Freshw. Biol. 51, 1389-1406 (2006)

13. W.L. Graf, Geomorphology 79, 336-360 (2006)

14. N.L. Poff, J.D. Olden, D.M. Merritt, D.M. Pepin, Proc. Natl. Acad. Sci. USA 104, 5732-5737 (2007)

15. R. Soja, Ł. Wiejaczka, Water Environ. J. 28, 473482 (2014)

16. M. Kędra, Ł. Wiejaczka, K. Wesoły, River Res. Applic. 32, 561-571 (2016)

17. N.L. Poff, D.D. Hart, BioScience 52, 659-668 (2002)

18. M. Kędra, Reservoir-induced changes in dynamics and synchrony of river water temperatures revealed by RQA and CRQA, in: Recurrence plots and their quantifications: expanding horizons (Springer Proceedings in Physics, vol. 180, Springer, pp. 289300, 2016)

19. M. Kędra, Ł. Wiejaczka, Water Environ. J. 30, 3139 (2016)

20. B.A. Sinokrot, H.G. Stefan, J.H. McCormick, J.G. Eaton, Clim. Change 30, 181-200 (1995)

21. R.D. Ries, S.A. Perry, Clim. Res. 5, 197-206 (1995)

22. B.W. Webb, Hydrol. Processes 10, 205-226 (1996)

23. O. Mohseni, T.R. Erickson, H.G. Stefan, Water Resour. Res. 35, 3723-3733 (1999)

24. O. Mohseni, H.G. Stefan, J.G. Eaton, Clim. Change 59, 389-409 (2003)

25. M. Daufresne, M.C. Roger, H. Capra, N. Lamouroux, Glob. Change Biol. 10, 124-140 (2004)
26. R.E. Hari, D.M. Livingstone, R. Siber, P. BurkhardtHolm, H. Güttinger, Glob. Change Biol. 12, 10-26 (2006)

27. M. Kędra, Water 9, 22 (2017)

28. D.L. Hartmann, A.M.G. Klein Tank, M. Rusticucci, L.V. Alexander, S. Brönnimann, Y. Charabi, F.J. Dentener, E.J. Dlugokencky, D.R. Easterling, A. Kaplan, B.J. Soden, P.W. Thorne, M. Wild, P.M. Zhai, Observations: Atmosphere and Surface, in: Climate Change 2013: The Physical Science Basis. Contribution of Working Group I to the Fifth Assessment Report of the Intergovernmental Panel on Climate Change (Cambridge University Press, 2013)

29. K.E. Trenberth, Clim. Res. 47, 123-138 (2011)

30. M. Acreman, M.J. Dunbar, Hydrol. Earth Syst. Sci. 8, 861-876 (2004)

31. W. Chełmicki, Location, classification and characteristics of the basin, in: The Upper Vistula Basin, part I (In Polish, PWN Warszawa-Kraków, pp. 15-29, 1991)

32. S. Węcławik, Geological structure, in: The Upper Vistula Basin, part I (In Polish, PWN WarszawaKraków, pp. 30-41, 1991)

33. T. Niedźwiedź, B. Obrębska-Starklowa, Climate, in: The Upper Vistula Basin, part I (In Polish, PWN Warszawa-Kraków, pp. 68-83, 1991)

34. CLC 2012, http://land.copernicus.eu/pan-european/ corine-land-cover (accessed 4 May 2017)

35. J. Hennig, I. Hennig, A. Roszkowski, Retention reservoirs, in: The Upper Vistula Basin, part II (PWN, Warszawa-Kraków, pp. 121-143, 1991) (In Polish)

36. H.B. Mann, Econometrica 13, 245-259 (1945)

37. M.G. Kendall, Rank correlation methods (4th ed. Charles Griffin, London, 1975)

38. D.R. Helsel, R.M. Hirsch, Statistical methods in water resources. Techniques of water-resources investigations (Book 4, U.S. Geological Survey, 2002) https://pubs.usgs.gov/twri/twri4a3/ (accessed 17 July 2017)

39. H. Theil, Proc. R. Neth. Acad. Arts Sci. 53, 386392, 521-525, 1397-1412 (1950)

40. P.K. Sen, J. Am. Stat. Assoc. 63, 1379-1389 (1968)

41. S. Yue, P. Pilon, B. Phinney, G. Cavadias, Hydrol. Process. 16, 1807-1829 (2002)

42. M.E. Power, A. Sun, G. Parker, W.E. Dietrich, J.T. Wootton, BioScience 45, 159-167 (1995)

43. M. Kędra, Clim. Res. 72, 251-265 (2017)

44. A. Björnsen Gurung, A. Bokwa, W. Chełmicki, M. Elbakidze M. Hirschmugl, P. Hostert, P. Ibisch, J. Kozak, T. Kuemmerle, E. Matei, K. Ostapowicz, J. Pociask-Karteczka, L. Schmidt, S. van der Linden, M. Zebisch, Mt. Res. Dev. 29, 282-288 (2009) 